\title{
Ecology, water and enterprise development in selected rural South African towns
}

\author{
DF Toerien* and MT Seaman \\ Centre for Environmental Management, University of the Free State, PO Box 339, Bloemfontein 9300, South Africa
}

\begin{abstract}
South Africa's imperatives for rural development and job creation raise the question whether water abundance in a region results in improved enterprise development in rural towns. The enterprise assemblages of 2 groups of towns, a river group from water-abundant areas and a Great Karoo group from the arid heartland of South Africa, were examined using a variety of different methods based on approaches used frequently in ecology. The comparisons included factors such as the ages of towns, clusters of towns and enterprise diversity. Although some hints were obtained that water abundance favoured enterprise development positively, the null hypothesis that water abundance would not influence enterprise development positively could not be rejected.

Several lessons were learnt: there are regularities in enterprise development whether in water-abundant or water-scarce areas; these regularities are understandable in terms of recent economic thinking as well as old concepts such as 'threshold populations'; money is the basic driver of enterprise success and more enterprises in one town than another reflects differences in the amount of money entering and/or circulating in towns; 'entrepreneurial space' in certain business sectors is used very effectively by 'run-of-the-mill entrepreneurs'; towns will give rise to different types of businesses and in proportion to the needs of the customers present in the towns; the degree of utilisation of certain business sectors differs statistically significantly between clusters of towns; and approaches and tools used effectively in the study of ecology offer many advantages for the study of enterprise development dynamics in towns, which are 'enterprise ecosystems'.

The mere presence of abundant water in a region does not automatically translate into enterprise development in towns. Entrepreneurial development should focus on ways and means to increase the flow of money into towns and not merely on its circulation within communities.
\end{abstract}

Keywords: South African towns; enterprise development; enterprise ecology; entrepreneurial space; water-abundant areas; water-scarce areas

\section{Introduction}

Rural development has become an important issue in South Africa. Gugile Nkwinti, the Minister of Rural Development and Land Reform, referred in the debate on the budget vote of his department (Nkwinti, 2010) to the resolution of the 52nd National Conference of the ANC of December 2007 on agrarian change, land reform and rural development. He stressed that it is Government's quest to create vibrant, equitable and sustainable rural communities and consequently it has adopted an Integrated Sustainable Rural Development Programme. He also stressed that: 'communities themselves have become central to their own development'.

South Africa is a water-constrained country (Ashton and Turton, 2008). Given government's determination to focus on creating vibrant, equitable and sustainable rural communities (Nkwinti, 2010), it is necessary to pose a question about the role of water availability in enterprise development in rural South African towns. It is more specifically necessary to ask if the presence of abundant water in a rural region has a measurable influence on enterprise development in towns of that region.

Central Place Theory has long dominated thinking about urban development in South Africa (e.g. Van der Merwe and Nel, 1975). Urban centres do not grow up by themselves;

\footnotetext{
* To whom all correspondence should be addressed.

苗 +2728 754 3623; fax: +2728 7543623 ; e-mail: Toeriend@ufs.ac.za

Received 28 June 2010; accepted in revised form 24 November 2010.
}

hinterlands set them up to do tasks that must be performed in central places (Myburgh, 1978). The wellbeing of hinterlands, therefore, should influence the fortunes of urban centres and help to ensure their sustainability. If more abundant water in a hinterland enhances hinterland prosperity, the urban centre dependent on the hinterland should also benefit.

Ferreira et al. (2007) investigated if a group of natural resource indicators (as measured by the availability of developable land, availability of water, agricultural potential, natural and cultural tourist attractions and environmental sensitivity) used by Van der Merwe et al. (2005) to rank 131 Western Cape towns would on their own provide a more concise surrogate instrument for evaluating growth and development potential of these towns. Whilst the larger towns in the selection were located in more water-rich parts of the Western Cape the results did not show a clear cut influence of water availability on the growth potential of towns (Ferreira et al., 2007).

To examine this question further it becomes necessary to consider new ideas about the functioning of the economy, i.e., that economic wealth and biological wealth are the same sort of phenomena thermodynamically, and not just metaphorically (Beinhocker, 2006). He pointed out that both are systems of low entropy, patterns of order that evolved over time under constraint of fitness functions. Toerien and Seaman (2010) pointed out that like each living organism, each individual enterprise is in a constant competition for survival and only the fittest survive. The enterprise survivors at any point in time determine the enterprise structure of towns. They postulated that towns are enterprise ecosystems and their enterprise structures reflect the driving forces and other factors impacting upon them. 


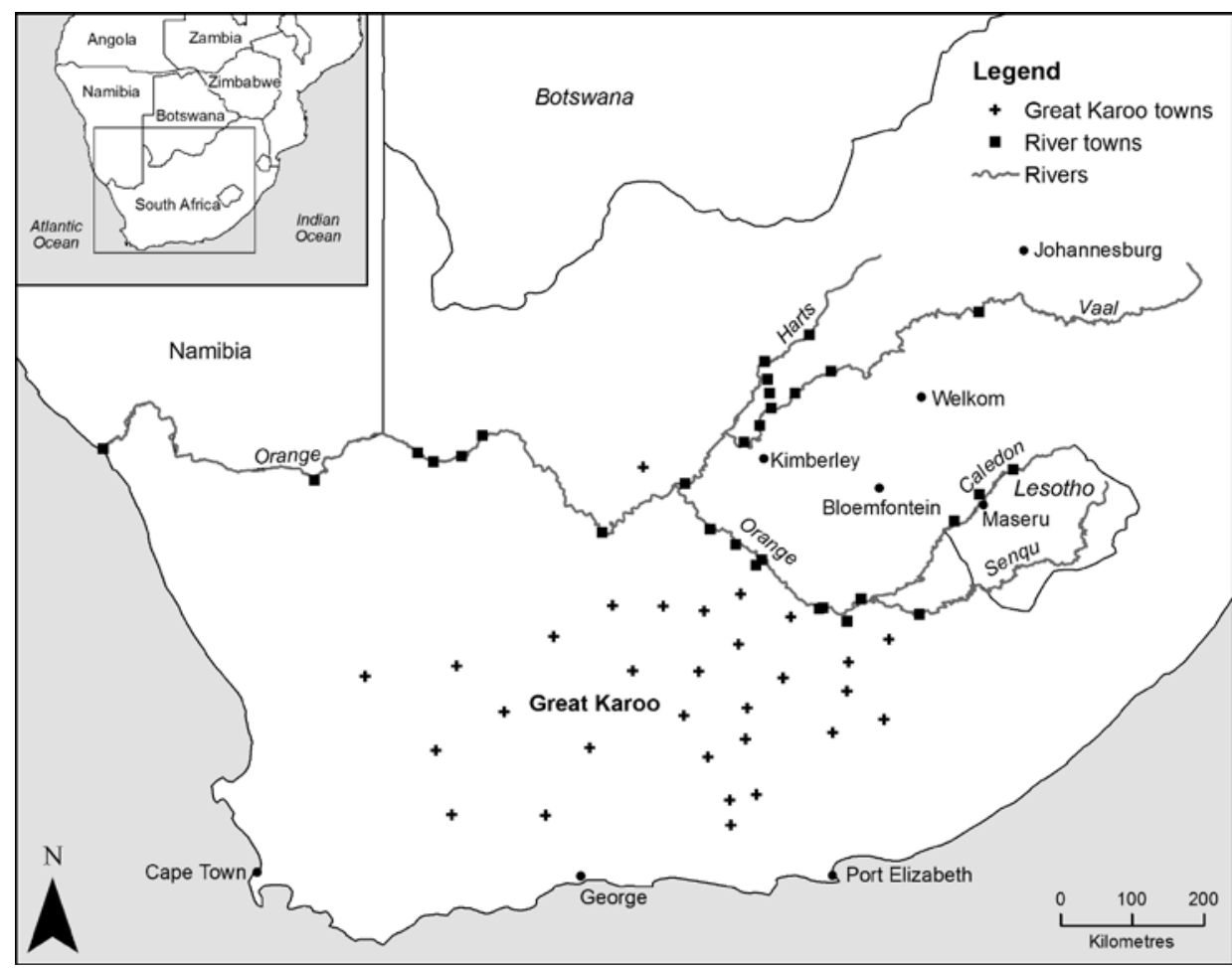

Figure 1

Location of the towns selected for the study

Using ecological techniques frequently applied to study biotic assemblages, they showed that towns of the semi-arid Karoo of South Africa have distinct cluster patterns that probably reflect their evolutionary paths from their origins as 'church towns' (a term used by Fransen (2006) that indicates that towns developed in the vicinity of the churches of new parishes established in rural South Africa in the $19^{\text {th }}$ and early $20^{\text {th }}$ centuries).

The Central Place Theory of urban development predicts that larger urban centres form hubs around which smaller urban centres congregate (Van der Merwe and Nel, 1975). Davies and Cook (1968) identified 8 levels or ranks among 601 South African urban settlements. To demonstrate that increased water availability in a hinterland enhances urban and enterprise development in its vicinity, therefore, requires dealing with the reality that both water-rich as well as water-poor areas will have ranges of town sizes and enterprise numbers. Answering the question is therefore, not a trivial exercise. The numbers and types of enterprises must be considered. In this regard, geographic economy and ecology both deal with questions of what is where and why, and the disciplines can learn from each other.

Toerien and Seaman (2010) concluded that towns are 'enterprise ecosystems' that house assemblages or communities of enterprises. Begon et al. (1990) considered the study of natural biological communities and remarked: 'It is, however, extraordinarily difficult to devise ways in which even very obvious similarities and differences between them [communities] can be described and measured.' The lesson from natural ecology is that a number of comparisons have to be made in order to detect differences or similarities.

The methods used by Toerien and Seaman (2010) offer an opportunity to investigate the question as to whether the presence of abundant water in a region has a measurable influence on enterprise development in towns of the region. A comparison of the enterprise structures of towns of a water-abundant area with those of an arid (water-scarce) area should answer the question posed. If there were no effect of the relative water abundance of an area on enterprise development in towns of such an area, the enterprise structures of water-abundant and water-poor areas should not differ quantitatively or qualitatively from each other.

The aim of this study was to examine if there are statistically significant similarities and differences between the enterprise structures of arid and water-abundant areas by using a number of methods used frequently in ecological studies. The null hypothesis was that relative water abundance would not lead quantitatively or qualitatively to differences in the formal enterprise structures of towns of arid and water-abundant regions.

\section{Methods}

\section{Region and towns selected for the study}

The Karoo occupies some $427000 \mathrm{~km}^{2}$ or $35 \%$ of South Africa (Cowling, 1986). Mean annual rainfall increases from less than $100 \mathrm{~mm}$ in the west to more than $400 \mathrm{~mm}$ in the east, but for most of the biome it rarely exceeds $250 \mathrm{~mm}$. The vegetation of the semi-arid area is a dwarf open shrub-land (Cowling, 1986). The Orange River rises in Lesotho and, together with its tributaries the Caledon and Vaal Rivers, drains a large part of South Africa, including the arid north-western part of the country (Fig. 1). The towns of this region provide an opportunity to test the null hypothesis outlined above.

Thirty villages and towns of the Great Karoo, not located on or close to the Orange River and its main tributaries, were selected to represent the sample of arid area towns (Table 1 and Fig. 1). The selection ranged from small villages with only 15 enterprises (Klipplaat and Philipstown) to a large town with 353 enterprises (Beaufort-West). Thirty villages and towns (Table 1) located on or near rivers of the Orange River Basin (hereafter called river towns) were selected to represent the sample of towns of a water-rich area (Table 2 and Fig. 1). The selection ranged from small villages with only 8 enterprises 


\begin{tabular}{|c|c|}
\hline \multicolumn{2}{|c|}{$\begin{array}{c}\text { Table } 1 \\
\text { The Great Karoo towns } \\
\text { selected for this study }\end{array}$} \\
\hline River towns & $\begin{array}{r}\text { Number of } \\
\text { enterprises }\end{array}$ \\
\hline Aberdeen & 39 \\
\hline Beaufort-West & 353 \\
\hline Britstown & 27 \\
\hline Burgersdorp & 115 \\
\hline Calvinia & 110 \\
\hline Carnarvon & 58 \\
\hline Colesberg & 144 \\
\hline Cradock & 296 \\
\hline De Aar & 223 \\
\hline Fraserburg & 33 \\
\hline Graaff-Reinet & 329 \\
\hline \begin{tabular}{|l|} 
Griekwastad \\
\end{tabular} & 31 \\
\hline Hanover & 22 \\
\hline Hofmeyr & 17 \\
\hline Jansenville & 47 \\
\hline Klipplaat & 15 \\
\hline Laingsburg & 56 \\
\hline Middelburg & 161 \\
\hline Murraysburg & 21 \\
\hline Nieu-Bethesda & 21 \\
\hline Philipstown & 15 \\
\hline \begin{tabular}{|l} 
Prince Albert \\
\end{tabular} & 72 \\
\hline Richmond & 30 \\
\hline Steynsburg & 39 \\
\hline Steytlerville & 30 \\
\hline Sutherland & 35 \\
\hline Tarkastad & 42 \\
\hline Victoria West & 74 \\
\hline Vosburg & 16 \\
\hline Williston & 26 \\
\hline
\end{tabular}

\begin{tabular}{|l|c|}
\hline \multicolumn{2}{|c|}{$\begin{array}{c}\text { Table 2 } \\
\text { Ther river towns selected } \\
\text { for this study }\end{array}$} \\
\hline River towns & $\begin{array}{c}\text { Number of } \\
\text { enterprises }\end{array}$ \\
\hline Alexander Bay & 55 \\
\hline Aliwal North & 266 \\
\hline Augrabies & 41 \\
\hline Barkly-West & 77 \\
\hline Bethulie & 43 \\
\hline Bloemhof & 120 \\
\hline Christiana & 137 \\
\hline Douglas & 127 \\
\hline Ficksburg & 299 \\
\hline Gariepdam & 21 \\
\hline Hartswater & 295 \\
\hline Hobhouse & 10 \\
\hline Hopetown & 70 \\
\hline Jan Kempdorp & 121 \\
\hline Kakamas & 138 \\
\hline Keimoes & 101 \\
\hline Ladybrand & 252 \\
\hline Norvalspont & 8 \\
\hline Orania & 28 \\
\hline Parys & 532 \\
\hline Pella & 8 \\
\hline Petrusville & 17 \\
\hline Prieska & 108 \\
\hline $\begin{array}{l}\text { Schweizer- } \\
\text { Reneke }\end{array}$ & 224 \\
\hline Taung & 91 \\
\hline Upington & 906 \\
\hline Vanderkloof & 18 \\
\hline Venterstad & 18 \\
\hline Warrenton & 90 \\
\hline Windsorton & 8 \\
\hline
\end{tabular}

(Norvalspont, Pella and Windsorton) to a large town with 906 enterprises (Upington).

The selected towns are mostly situated in the heartland of South Africa, a mostly arid area. The Orange River passes through this area before reaching the Atlantic Ocean at Alexander Bay. The Karoo biome is mostly suitable only for stock production (Cowling, 1986) and associated products such as wool and mohair. However, the presence of significant rivers in the arid region creates additional agricultural possibilities such as irrigation farming. The question is if this would have significant effects on enterprise development in the towns of the region?

\section{Determination of formal enterprise assemblages}

The rapid method to determine the formal enterprise assemblages of South African towns drew upon ecological experiences in the study of biotic assemblages of aquatic ecosystems (Toerien and Seaman, 2010). It is based on listings of enterprises in telephone directories. All enterprises listed in such directories form part of the formal economy of the towns in which they reside and their enumeration allows valid comparisons between towns (Toerien and Seaman, 2010). Telephone directories of the selected towns were scrutinised (Tables 1 and 2) and all enterprises were listed in spreadsheets and categorised using 19 major enterprise sectors, which included economic drivers and service providers (Table 3). When it was impossible to deduce the nature

\begin{tabular}{|l|l|}
\hline \multicolumn{2}{|c|}{ Table 3} \\
Enterprise sectors used in classifications \\
\hline No. & Economic drivers \\
\hline 1 & Agricultural products and services sector \\
\hline 2 & Processing sector \\
\hline 3 & Factory sector \\
\hline 4 & Construction sector \\
\hline 5 & Mining sector \\
\hline 6 & Tourism and hospitality sector \\
\hline & Service sectors \\
\hline 7 & Engineering and technical services sector \\
\hline 8 & Financial services sector \\
\hline 9 & Legal services sector \\
\hline 10 & Telecommunications services sector \\
\hline 11 & News and advertising services sector \\
\hline 12 & Trade sector \\
\hline 13 & Vehicle sector \\
\hline 14 & General services sector \\
\hline 15 & Professional services sector \\
\hline 16 & Personal services sector \\
\hline 17 & Health services sector \\
\hline 18 & Transport and earthworks sector \\
\hline 19 & Real estate sector \\
\hline & \\
\hline
\end{tabular}

of an enterprise from its name in the telephone directory and/ or from an internet search, the entry was not used in subsequent analyses. The identified enterprises in every enterprise sector of each town were counted to develop an enterprise assemblage profile for each town of every selected group.

\section{Economic drivers}

Toerien and Seaman (2010) identified 6 sectors as economic drivers in rural South African towns (i.e. the principal sectors that bring money into towns; Table 3). Most rural towns in South Africa were dependent on agriculture and, thus, an agricultural products and services sector became very important in these towns. In time, some processors started adding value to local primary produce and the processing sector developed. Some entrepreneurs also realised that they could add value to materials from outside their regions and thus factories and the factory sector began to develop. Travellers also traversed rural areas and needed accommodation and food, which resulted in the development of a tourism and hospitality sector. The subsequent need to build houses and businesses stimulated a construction industry, often dependent on investments from outside a region. The discovery of diamonds in 1866 and subsequently gold and other minerals also stimulated the development of a mining sector in South Africa.

\section{Service providers}

Thirteen different service sectors are active in rural towns of South Africa (Toerien and Seaman, 2010) (Table 3). These sectors are probably more important for the circulation of money within the towns than for the generation of new money inflows.

\section{Experimental design}

The 2 groups (of similar size: 30 river towns and 30 Karoo towns) and each spanning the range from small villages to large towns were, where appropriate, analysed separately as 
well as in combination (referred to as the super-group). Several elements of the enterprise structures of towns can be used in such comparisons, i.e:

- The number of enterprises in the towns of a specific group and their distribution characteristics

- The ages of towns in a specific group

- The distribution characteristics of town ages

- The clusters of towns of the 2 groups based on enterprise assemblages. (In addition the clusters of the super-group including all of the towns were examined.)

- The presence of statistical differences between clusters of the super-group

- Business diversity of the enterprise structures of the 2 groups

All of these elements were investigated as explained below.

\section{Enterprise numbers and their distribution characteristics}

WINKS SDA Software (6th edition) obtained from TexaSoft, Cedar Hill, USA was used to compare the enterprise numbers of the 2 groups and to determine their statistical distribution characteristics.

Earlier unpublished research on the enterprise assemblages of South African towns suggested that there is a surprising regularity (proportionality) between the total number of enterprises in towns and the number of enterprises in specific business sectors. This phenomenon could also be used to compare the river and Karoo towns with each other. Pearson correlations and regression equations were calculated between the total number of enterprises in the towns of a group and the number of enterprises of each business sector per town and for each group. Microsoft Excel software was used for these calculations.

\section{The impact of town age on enterprise structures}

Because it is possible that the ages of towns might cause differences between river and Karoo Towns, the age (in 2009) distribution characteristics of the towns were compared. WINKS SDA Software was also used for this purpose. The age of towns was derived from either Fransen (2006) or Erasmus (2004). The age of the village of Klipplaat could neither be derived from these sources nor from an internet search, and the village was excluded from this analysis.

\section{Normalisation of data}

The clustering and ordination of enterprise assemblages of differing sizes required normalisation of the data by expressing the numbers of enterprises in each enterprise sector as a percentage of the total number of enterprises in specific towns.

\section{Similarities of enterprise assemblages of villages and towns and cluster analyses of enterprise assemblages}

Similarly to Toerien and Seaman (2010), the computer software package PRIMER (Plymouth Routines in Multivariate Ecological Research) obtained from PRIMER-E Ltd, Plymouth, UK, was used to examine the similarities or differences (Clarke and Gorley, 2006) of the enterprise assemblages of the 2 groups and the super-group.

\section{Resemblance of enterprise assemblages}

Pearson correlation coefficients based on the normalised data were calculated with the aid of PRIMER software between each of the possible pairs of villages and towns in each group. This resulted in 2 correlation coefficient similarity matrices detailing the similarities between every possible pair of towns or villages of each group. In addition, the towns and villages of both groups were combined in a super-group and a correlation coefficient similarity matrix was calculated for the super-group.

\section{Cluster analyses}

The aim of cluster analysis is to find 'natural groupings' of samples, such that samples within a group are generally more similar to one another than samples in different groups (Clarke and Gorley, 2006). The separate cluster analyses of the river towns and Karoo towns delineate their separate enterprise ecosystems. The cluster analysis of the super-group assisted the identification of unique clusters, if any, of Karoo or river towns within the cluster analysis of the total sample (60) of towns.

The most commonly used clustering techniques are hierarchical agglomerative methods that usually take a similarity matrix as their starting point and successively fuse the samples (i.e. towns in this study) into sub-clusters and these into larger clusters, starting with the highest mutual similarities and then gradually lowering the similarity level at which groups are formed (Clarke and Warwick, 2001). The results can be represented in dendrograms through use of one of the software (PRIMER) options.

The software offers 3 linkage options when constructing dendrograms, namely single linkage (nearest neighbour), group-average and complete linkage (furthest neighbour) clustering (Clarke and Gorley, 2006). The complete linkage option was used, similarly to Toerien and Seaman (2010). The correlation coefficient similarity matrices (see earlier explanation) of the river, Great Karoo and super-groups were the inputs of the 3 cluster analyses.

To detect unique features of clusters of the super-group, its dendrogram was analysed from 3 points of view:

- Similarity to the type of pattern observed for the river and Great Karoo towns

- Origin of the towns in clusters

- Presence of statistically significant differences between clusters of towns

\section{Testing the statistical significance of clusters}

Non-parametric statistical techniques were used to test for the presence of statistically significant differences between the clusters of the super-group. A combination of the KruskalWallis non-parametric test and the Tukey test (Dytham, 2003) was employed using WINKS SDA Software. Because of the nature of non-parametric statistical methods, clusters with only 2 members were excluded from these analyses.

\section{Graphical comparison of the clusters of the super- group}

Graphical comparisons were used to augment the statistical comparisons of the clusters of the super-group. The towns were arranged in the order produced by the cluster analysis of the super-group and graphs were constructed to depict similarities of and differences between the different clusters.

\section{Business diversity of the enterprise structures of the two groups}

Species diversity is an important attribute of natural ecosystems and higher diversity is widely, but not universally, thought to be associated with ecosystem stability (Begon et al., 1990). 
The diversity of enterprises in towns, as enterprise ecosystems, can therefore be considered to be an important attribute that may be used to assess the impact of water abundance on enterprise development in towns. More specifically, the question was addressed as to whether more abundant water would lead to river towns having more diverse and hence more stable enterprise structures in general?

This study measured enterprise diversity for a specific town simply as the number of enterprise sectors that have at least one enterprise each. An Enterprise Diversity Index (EDI) was calculated for each town as the number of sectors with representatives as a percentage of the 19 sectors used in the study. The EDIs for the river and Karoo towns were compared.

\section{Results}

\section{Enterprise numbers}

The size of the enterprise assemblages of both river towns and Karoo towns ranged from villages to large towns. Some river villages had only 8 enterprises and some Karoo villages only 15 enterprises (Table 4). A large river town, Upington, had 906 and a large Karoo town, Beaufort-West, had 353 enterprises.

The river towns seem to have somewhat larger enterprise structures as suggested by a higher median enterprise number (Table 4). A frequency distribution of the enterprise sizes of towns (Fig. 2) suggests that the Karoo towns are generally somewhat smaller than the river towns. However, in a non-parametric Mann-Whitney comparison (necessitated because the number of enterprises were not normally distributed, see Table 4) of the 2 groups the $z$-value of 1.064 is only significant at $p=$ 0.287 , not low enough to be considered statistically significant (Table 4). The mere abundance of water close to river towns did

\begin{tabular}{|l|c|c|}
\hline \multicolumn{3}{|c|}{$\begin{array}{c}\text { Table } \mathbf{4} \\
\text { Komparison of enterprise numbers of river and } \\
\text { Karoo towns }\end{array}$} \\
\hline Characteristic & $\begin{array}{c}\text { River towns } \\
(n=\mathbf{3 0})\end{array}$ & $\begin{array}{c}\text { Karoo towns } \\
(n=\mathbf{3 0})\end{array}$ \\
\hline Minimum number & 8 & 15 \\
\hline Maximum number & 906 & 353 \\
\hline Median & 91 & 39 \\
\hline Distribution & Not normal & Not normal \\
\hline $\begin{array}{l}\text { Mann-Whitney comparison } \\
\text { of enterprise numbers }\end{array}$ & $\begin{array}{l}Z=1.064 \text { and } p=0.287 . \\
\text { Difference not statistically } \\
\text { significant. }\end{array}$ \\
\hline
\end{tabular}

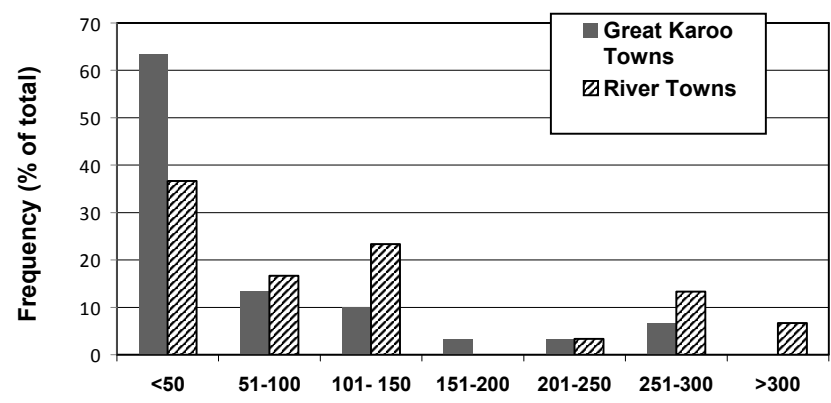

Interval sizes (number of enterprises)

Figure 2

Frequency distribution of the enterprise sizes of selected towns

not necessarily result in generally larger enterprise structures. However, a comparison of the sizes of the largest towns of each group (river towns: Upington with 906 enterprises and Karoo towns: Beaufort-West with 353 enterprises) suggests that it is probably possible to develop much larger towns in water-abundant than in arid areas.

To assess if water abundance influences the composition of enterprise assemblages of towns, the regularities/irregularities (proportionalities) between sector enterprise numbers (dependent variables) and total enterprise numbers (independent variables) were established. These are summarised for the economic driver sectors in Table 5 and for the service sectors in Table 6. These tables suggest that the enterprise development dynamics for most business sectors are fairly similar across the 2 selected groups of towns, a fact supported graphically in Fig. 3, where the relationship between the number of traders per town $v i s-\grave{a}$-vis the total number of enterprises per town is used as a general illustration of the above statement.

An outstanding feature of Tables 5 and 6 is that large parts of the variances of sector enterprise numbers (at least $68 \%$ and as high as $99 \%$ ) are explained by the relationships between sector totals and the total number of enterprise numbers. In both groups enterprise development is by and large not haphazard and 'entrepreneurial space' is occupied in an orderly and predictable fashion.

Three economic driver sectors do not fit this general picture (Table 5). In the case of the processing and factory sectors the regression equations of the river towns explain nearly 83 and

\begin{tabular}{|c|c|c|c|c|c|c|}
\hline \multicolumn{7}{|c|}{$\begin{array}{c}\text { Table } 5 \\
\text { Regularity/irregularity in the economic driver sectors of selected groups }\end{array}$} \\
\hline Sectors & $\begin{array}{l}\text { Agricultural } \\
\text { products and } \\
\text { services }\end{array}$ & Processors & Factories & Construction & Mining & $\begin{array}{c}\text { Tourism and } \\
\text { hospitality }\end{array}$ \\
\hline \multicolumn{7}{|c|}{ River towns } \\
\hline Correlation & 0.84 & 0.91 & 0.78 & 0.97 & 0.15 & 0.94 \\
\hline Variance explained (\%) & 70.2 & 82.6 & 61.4 & 94.1 & 2.2 & 88.8 \\
\hline Regression coefficient & 0.0495 & 0.0163 & 0.0085 & 0.0572 & 0.0016 & 0.0861 \\
\hline Intercept & 3.1 & 0.2 & -0.3 & -1.7 & 0.8 & 0.2 \\
\hline \multicolumn{7}{|c|}{ Karoo towns } \\
\hline Correlation & 0.83 & 0.71 & 0.49 & 0.93 & -0.20 & 0.90 \\
\hline Variance explained (\%) & 68.6 & 49.9 & 24.4 & 86.6 & 4.0 & 81.6 \\
\hline Regression coefficient & 0.0458 & 0.013 & 0.002 & 0.0690 & -0.0006 & 0.13 \\
\hline Intercept & 2.3 & -0.1 & 0.0 & -2.0 & 0.2 & 2.1 \\
\hline
\end{tabular}


River and Karoo Towns

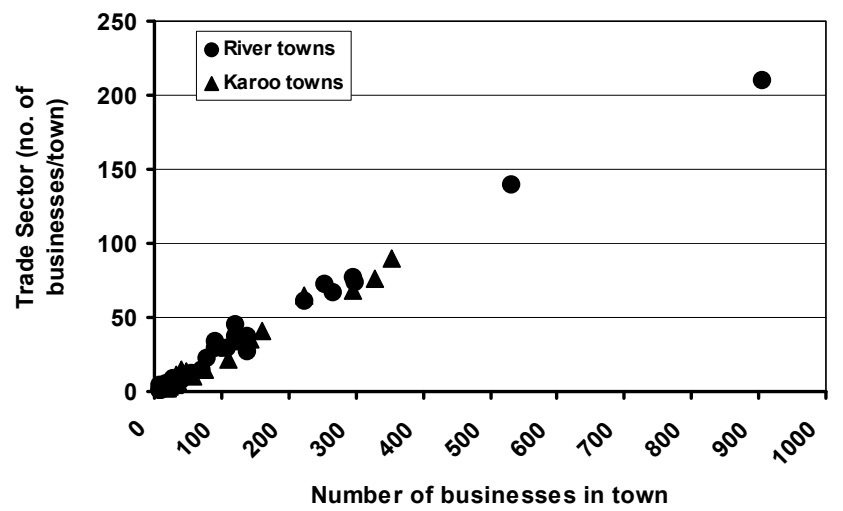

Figure 3

The relationship of the number of trade enterprises per town versus the total number of enterprises per town of the selected groups

$61 \%$ of the variances, respectively, but for the Karoo towns only 50 and $24 \%$, respectively (Table 5). Larger river towns are more likely to have more processing and factory enterprises than smaller river towns. This is not the case in Karoo towns where smaller towns can have more of these enterprises than larger towns. The differences between groups are perhaps explained by differences in agricultural activities, e.g., irrigation farming in the case of the river towns versus stock farming on Karoo farms. Entrepreneurship rather than the size of towns evidently plays a more significant role in the establishment of

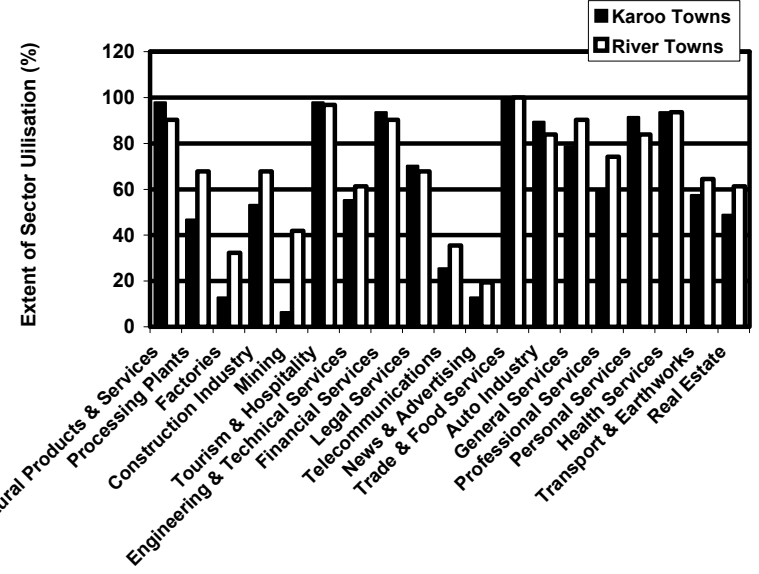

Figure 4

Utilisation of different business sectors by the towns of the river and Great Karoo groups

such enterprises in the Karoo.

The processing sector, which adds value to local primary products, and the factory sector that adds value to primary and other products from elsewhere, offer possibilities (Toerien, 2005) to create new income streams for the towns of both the water-abundant and arid regions. The former seem to utilise these opportunities better than the latter (Fig. 4); however, both groups have ample scope for expansion in these two sectors.

The third sector, mining, is dependent on mineral and other deposits and if an area is mineral poor there is nothing that

\begin{tabular}{|c|c|c|c|c|c|c|c|}
\hline \multicolumn{8}{|c|}{$\begin{array}{c}\text { Table } 6 \\
\text { Regularity/irregularity in the service }\end{array}$} \\
\hline \multicolumn{8}{|c|}{ River towns } \\
\hline Sectors & $\begin{array}{c}\text { Engineering } \\
\text { and technical } \\
\text { services }\end{array}$ & $\begin{array}{l}\text { Financial } \\
\text { services }\end{array}$ & Legal services & $\begin{array}{l}\text { Telecommuni- } \\
\text { cation } \\
\text { services }\end{array}$ & $\begin{array}{l}\text { News and } \\
\text { advertising }\end{array}$ & Trade & Vehicle sector \\
\hline Correlation & 0.91 & 0.97 & 0.87 & 0.90 & 0.84 & 0.99 & 0.98 \\
\hline Variance explained (\%) & 81.9 & 93.4 & 76.2 & 81.8 & 70.0 & 98.5 & 96.2 \\
\hline Regression coefficient & 0.0335 & 0.0699 & 0.014 & 0.0175 & 0.0023 & 0.2408 & 0.1177 \\
\hline Intercept & -1.1 & 1.8 & 0.7 & -1.0 & -0.1 & 3.0 & -2.3 \\
\hline \multicolumn{8}{|c|}{ River towns } \\
\hline Sectors & & $\begin{array}{c}\text { General } \\
\text { services }\end{array}$ & $\begin{array}{c}\text { Professional } \\
\text { services }\end{array}$ & $\begin{array}{l}\text { Personal } \\
\text { services }\end{array}$ & $\begin{array}{l}\text { Health } \\
\text { services }\end{array}$ & $\begin{array}{c}\text { Transport and } \\
\text { earthworks }\end{array}$ & Real estate \\
\hline Correlation & & 0.98 & 0.94 & 0.98 & 0.98 & 0.92 & 0.88 \\
\hline Variance explained (\%) & & 96.1 & 88.8 & 96.5 & 96.4 & 84.2 & 77.3 \\
\hline Regression coefficient & & 0.061 & 0.0244 & 0.0656 & 0.0659 & 0.0407 & 0.0275 \\
\hline Intercept & & -1.5 & 0.2 & 0.8 & 0.2 & -2.0 & -1.1 \\
\hline \multicolumn{8}{|c|}{ Karoo towns } \\
\hline Sectors & $\begin{array}{l}\text { Engineering } \\
\text { and technical } \\
\text { services }\end{array}$ & $\begin{array}{l}\text { Financial } \\
\text { services }\end{array}$ & Legal services & $\begin{array}{l}\text { Telecommuni- } \\
\text { cation } \\
\text { services }\end{array}$ & $\begin{array}{l}\text { News and } \\
\text { advertising }\end{array}$ & Trade & Vehicle sector \\
\hline Correlation & 0.85 & 0.96 & 0.87 & 0.84 & 0.71 & 0.99 & 0.97 \\
\hline Variance explained (\%) & 72.2 & 93.0 & 76.0 & 71.3 & 49.9 & 97.8 & 94.4 \\
\hline Regression coefficient & 0.0245 & 0.0697 & 0.0167 & 0.01 & 0.0041 & 0.2472 & 0.1006 \\
\hline Intercept & -0.1 & 0.4 & 0.3 & -0.2 & -0.1 & -0.2 & -1.2 \\
\hline \multicolumn{8}{|c|}{ Karoo towns } \\
\hline Sectors & & $\begin{array}{l}\text { General } \\
\text { services }\end{array}$ & $\begin{array}{c}\text { Professional } \\
\text { services }\end{array}$ & $\begin{array}{l}\text { Personal } \\
\text { services }\end{array}$ & $\begin{array}{l}\text { Health } \\
\text { services }\end{array}$ & $\begin{array}{c}\text { Transport and } \\
\text { earthworks }\end{array}$ & Real estate \\
\hline Correlation & & 0.95 & 0.94 & 0.95 & 0.91 & 0.90 & 0.89 \\
\hline Variance explained (\%) & & 90.7 & 87.4 & 90.8 & 83.2 & 80.4 & 80.0 \\
\hline Regression coefficient & & 0.0522 & 0.0367 & 0.0719 & 0.0562 & 0.0274 & 0.0237 \\
\hline Intercept & & -0.7 & -0.8 & 0.1 & 0.7 & -0.2 & -0.4 \\
\hline
\end{tabular}




\begin{tabular}{|c|c|c|}
\hline \multicolumn{3}{|c|}{$\begin{array}{c}\text { Table } 7 \\
\text { Comparison of the ages of Karoo and river towns }\end{array}$} \\
\hline Characteristic & $\begin{array}{l}\text { River towns } \\
\quad(n=30)\end{array}$ & $\begin{array}{l}\text { Karoo towns } \\
(n=29)\end{array}$ \\
\hline Minimum age & 29 & 105 \\
\hline Maximum age & 204 & 224 \\
\hline Median & 134 & 155 \\
\hline Distribution & Not normal & Not normal \\
\hline $\begin{array}{l}\text { Mann-Whitney } \\
\text { comparison } \\
\text { of town ages }\end{array}$ & \multicolumn{2}{|c|}{$\begin{array}{l}Z=3.48 \text { and } p=<0.001 \\
\text { Karoo towns are highly significantly } \\
\text { older }\end{array}$} \\
\hline
\end{tabular}

can be done to strengthen this sector. This is the case for most of the river and all of the Great Karoo towns, with the former stronger than the latter (Fig. 4).

Among the service sectors, the news and advertising sector also does not exhibit regularity, especially for the Karoo town group where only approximately $50 \%$ of the variance was explained (Table 6). More of the river towns utilise this business sector as well as the telecommunications sector (Fig. 4) slightly better than the Karoo towns. Water abundance seems to have little impact on these business sectors.

An outstanding feature of Tables 5 and 6 is that generally more of the variance is explained by the regression equations of the river town group than by the regression equations of the Karoo town group. This might be indicative of inherently more unstable enterprise development dynamics under arid conditions, and vice versa.

\section{The impact of town age on enterprise numbers}

It was necessary to determine if any differences observed between groups were a result of differing town ages. A nonparametric Mann-Whitney comparison (because the town ages of the river towns are not normally distributed) of the ages of river and Karoo towns is presented in Table 7. The selected Karoo towns are significantly $(Z=3.48$ and $p=<0.001)$ older than the selected river towns. Despite their relative youth, the 2 largest enterprise assemblages in the selected towns occur in the river group (Upington and Parys, Table 4) perhaps indicative of an ability to grow larger enterprise assemblages more rapidly in water-abundant areas.

\section{Clustering of the groups of towns and the super- group of towns}

The cluster diagrams of the river towns, the Karoo towns and the super-group are presented in Figs. 5, 6 and 7 respectively. All of the diagrams have a common feature, i.e., that at a very low correlation level there is a relatively small group of towns linked to a much larger group of towns (Figs. 5, 6 and 7).

The larger group in the river towns consists of 2 clusters (at $r=0.6$ level), the one having 9 member towns and the other having 13 (Fig. 5). The smaller group have 3 clusters (defined at $r=0.6), 2$ clusters containing 2 towns and the other containing 4 towns (Fig. 5). The larger group in the Great Karoo towns consists of 3 clusters (at $r=0.6$ level); one having 12 member towns, the second having 10 member towns and the last having only 2 member towns (Fig. 6). The smaller group of Great Karoo towns have a single cluster (defined at $r=0.6$ ) and a single outlier (Fig. 6).

Overall, it appeared as if there were different clusters of

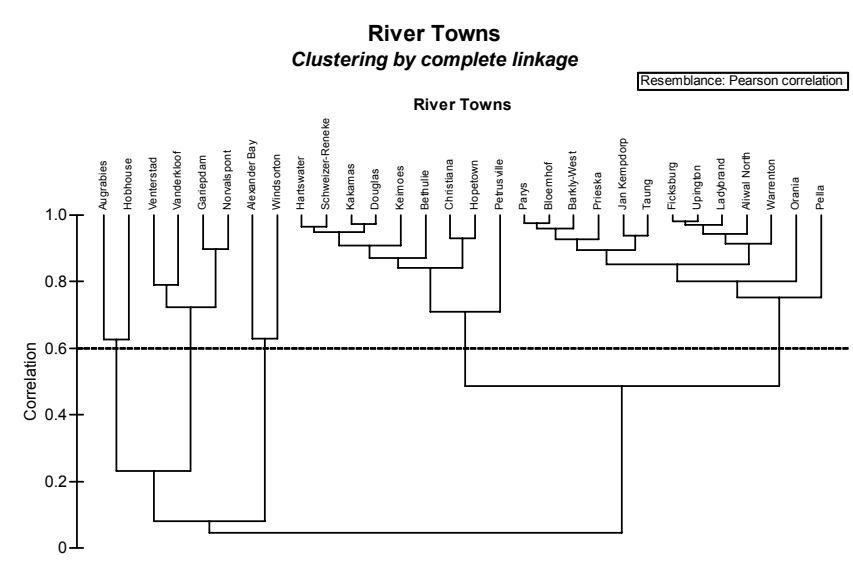

Figure 5

Clusters of 30 river towns

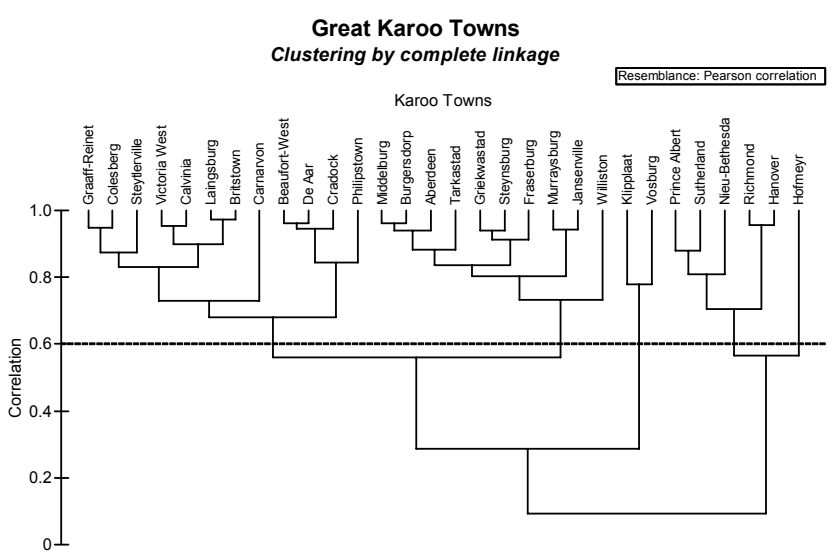

Figure 6

Clusters of 30 Great Karoo towns

River \& Great Karoo Towns Clustering by complete linkage

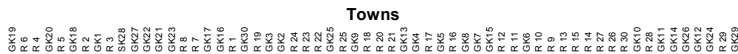

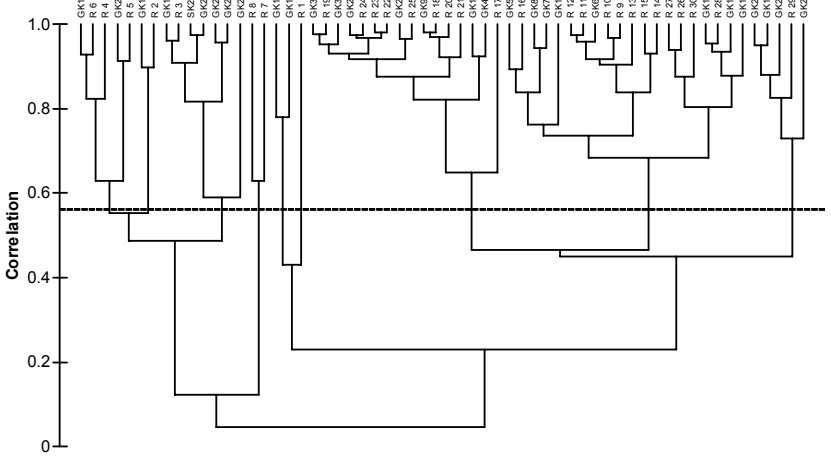

Figure 7

Super-clusters of 30 river and 30 Great Karoo towns.

$R$ indicates river town and GK indicates Great Karoo town.

towns in the 2 groups (river towns vis-à-vis Karoo towns). This contention was further studied by examining the origin of towns in the clusters of the super-group (Fig. 7). Similarly to the river and Great Karoo groups the super-group also consists of 2 groups linked at a very low correlation. The smaller group has 16 members and is divided into 4 clusters; one with 7 members, one with 5 members and 2 clusters with 2 members. The larger group (44 member towns) contains a small group of 3 


\begin{tabular}{|l|l|l|l|l|l|l|l|l|l|l|}
\hline \multicolumn{10}{|c|}{ Table 8} \\
\multicolumn{10}{|c|}{ Clusters of the super-group and the origin of towns } \\
\hline Cluster & 1 & 2 & 3 & 4 & 5 & 6 & 7 & 8 & outliers \\
\hline $\begin{array}{l}\text { Number } \\
\text { of towns }\end{array}$ & $5^{*}$ & 2 & $7 *$ & 2 & 2 & $16^{*}$ & $20^{*}$ & $5^{*}$ & 1 \\
\hline Origin & $3 \mathrm{R}$ & $1 \mathrm{R}$ & $1 \mathrm{R}$ & $2 \mathrm{R}$ & $2 \mathrm{GK}$ & $\begin{array}{l}9 \mathrm{R} \\
7 \mathrm{GK}\end{array}$ & $\begin{array}{l}12 \mathrm{R} \\
8 \mathrm{GK}\end{array}$ & $\begin{array}{l}1 \mathrm{R} \\
4 \mathrm{GK}\end{array}$ & \\
& $2 \mathrm{GK}$ & $1 \mathrm{GK}$ & $6 \mathrm{GK}$ & & & 7 &
\end{tabular}

$*=$ used in statistical comparisons of clusters, $R=$ River town, GK = Great Karoo town

Clusters of River and Great Karoo Towns

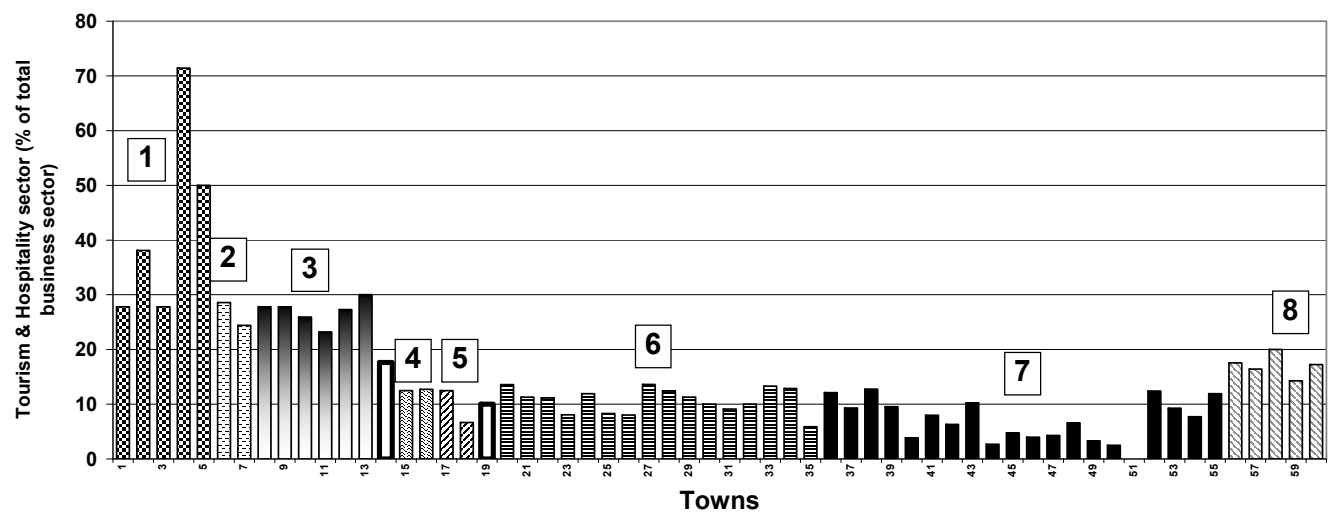

Figure 8

The tourism and hospitality sector of the different clusters of the super-group towns (one cluster of 2 towns and one outlier) and a large group (41 towns) linked at a correlation of 0.23 . The large group contains 3 clusters (defined at $r=0.56$ ); one with 16 member towns, the second with 20 member towns and the third with 5 member towns (Fig. 7). Table 8 summarises the clusters, their constituent sizes and composition.

As far as the location of the towns in the study areas is concerned it is significant that only 2 small clusters (No. 4 and 5 , Table 8 ) were each derived from a single group. Otherwise all clusters had a mixture of representatives from the 2 groups. This suggests that water abundance or scarcity does not overly impact the composition of business development in towns. However, this issue needed further graphical and statistical analyses.

Statistical comparisons consisting of Kruskal-Wallis and Tukey tests of Clusters 1, 3, 6, 7 and 8 are summarised in Table 9. Eight sectors, namely, processing, mining, legal services, telecommunication services, general services, professional services, transport and earthworks, and real estate services did not have any significant differences between clusters according to the Tukey test (Table 9). The other 11 sectors had one or more significant differences. The tourism and hospitality sector and the vehicle sector had the most (5) significant differences between clusters. Figure 8 provides a visualisation of the differences between clusters. Due to space limitations, the rest of the graphs are not shown but they confirm the results of the statistical analyses.

\section{Enterprise diversity of the river and Great Karoo groups}

The EDIs of the 2 groups in relation to the size of the enterprise assemblages of the different towns are presented in Fig. 9. There is little, if any, difference in EDIs between the 2 groups. In both cases the EDI is low in villages and small towns. It rises rapidly when the size of enterprise assemblages increases to about 100 enterprises. Thereafter it stays fairly constant. There is no discernible influence of water abundance or scarcity on this parameter.
Enterprise Diversity in River and Karoo Towns

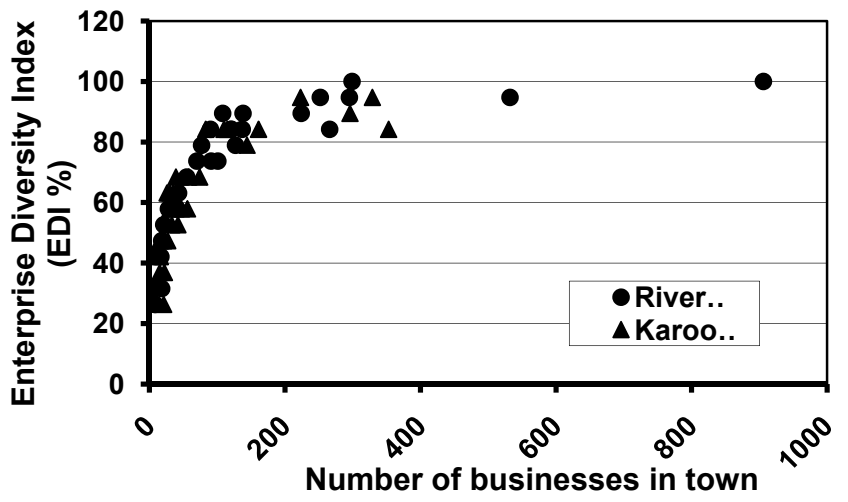

Figure 9

Enterprise diversity of the river and Great Karoo towns

\section{Discussion}

This study has not detected major impacts of water abundance on the quantity nor quality of enterprise assemblages of the towns in water-abundant or water-restricted areas. There are, however, hints of subtle influences that need consideration.

The towns of the arid Great Karoo are older than the river towns (Table 7). The Great Karoo was initially settled by 'trekboers' who were subsistence stock farmers (Giliomee and Mbenga, 2007). Later a switch was made to wool farming, which was for a long time a major earner of foreign exchange for the Cape Colony and later South Africa (Wickins, 1983). Despite the age advantage of Karoo towns and their association with a major export staple, the river group has achieved a higher enterprise median per town (Fig. 2, Table 4). This group also includes the 2 towns with the most enterprises of the total study selection, i.e. Parys and Upington (Table 2). In addition, the enterprise 


\begin{tabular}{|c|c|c|c|c|}
\hline $\begin{array}{r}\text { Krus } \\
80\end{array}$ & $\begin{array}{l}\text { kal-Wallis and Tuke } \\
\text { the super group. C }\end{array}$ & $\begin{array}{l}\text { sts o } \\
\text { ers li } \\
\text { sign }\end{array}$ & $\begin{array}{l}\text { le } 9 \\
\text { usiness } \\
\text { y a dot } \\
\text { ly }(p=0\end{array}$ & $\begin{array}{l}\text { lusters } 1,3,6,7 \text { and } \\
\text { t differ statistically }\end{array}$ \\
\hline No. & Business sector & Krus & Ilis test & Tukey test ${ }^{*}$ \\
\hline & & $H$ & $P$ & \\
\hline 1 & $\begin{array}{l}\text { Agricultural products } \\
\text { and services }\end{array}$ & 19.5 & $<0.001$ & $\begin{array}{r}16837 \\
-1\end{array}$ \\
\hline 2 & Processing & 2.4 & 0.655 & 18376 \\
\hline 3 & Factories & 11.3 & 0.024 & 38716 \\
\hline 4 & Construction & 26.2 & $<0.001$ & 13768 \\
\hline & & & & ------- \\
\hline 5 & Mining & 7.2 & 0.126 & 13867 \\
\hline 6 & $\begin{array}{l}\text { Tourism and } \\
\text { hospitality }\end{array}$ & 39.0 & $<0.001$ & $\begin{array}{c}76831 \\
-1 \\
----\end{array}$ \\
\hline 7 & $\begin{array}{l}\text { Engineering and } \\
\text { technical services }\end{array}$ & 12.4 & 0.015 & $\begin{array}{c}16738 \\
-1 .---\end{array}$ \\
\hline 8 & Financial services & 13.3 & 0.01 & 13867 \\
\hline 9 & Legal services & 2.1 & 0.709 & 37618 \\
\hline 10 & Telecommunications & 5.7 & 0.223 & 38176 \\
\hline 11 & News and advertising & 13.9 & 0.008 & 13876 \\
\hline 12 & Trade & 19.2 & $<0.001$ & 31867 \\
\hline 13 & Vehicle sector & 29.1 & $<0.001$ & 18673 \\
\hline 14 & General services & 8.8 & 0.067 & 73186 \\
\hline 15 & Professional services & 5.1 & 0.282 & 36178 \\
\hline 16 & Personal services & 12.0 & 0.018 & $\begin{array}{c}16837 \\
-\end{array}$ \\
\hline 17 & Health services & 12.5 & 0.015 & 83671 \\
\hline 18 & $\begin{array}{l}\text { Transport and } \\
\text { earthworks }\end{array}$ & 8.7 & 0.07 & 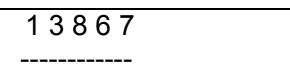 \\
\hline 19 & Real estate & 1.9 & 0.746 & 37186 \\
\hline & $\begin{array}{l}\text { Size of enterprise } \\
\text { structure }\end{array}$ & 13.5 & 0.01 & $\begin{array}{r}13876 \\
- \\
-\end{array}$ \\
\hline
\end{tabular}

$*=$ numbers are cluster numbers and represent higher numbers in the sector to the right. Clusters underlined by a single line do not differ at $p=0.05$.

development dynamics of water-abundant areas might be more stable than in water-scarce areas. However, there was no constant detectable benefit for enterprise development from water abundance and the null hypothesis could not be rejected.

What then are the lessons, if any, to be learnt from this exercise? First and foremost is the pattern of regularities (proportionalities) in enterprise development observed in a number of towns (Tables 5 and 6), be they from the Great Karoo or from water-abundant areas. This phenomenon is understandable both in terms of recent economic thinking (Beinhocker, 2006) as well as the old concept of 'threshold populations' used in considerations of urban development in the 1970s (Van der Merwe and Nel, 1975).

Beinhocker (2006 p. 280) defined a business (the word enterprise is used here) as 'a person, or organized group of people, who transforms matter, energy, and information from one 
state into another with the goal of making a profit.' Because the economy is subject to the second law of thermodynamics, businesses have to overcome entropy (Beinhocker, 2006). Based on the above definition an enterprise only becomes a viable proposition if there are enough clients to buy its products and/or services to make a profit. Money is, therefore, the basic driver of enterprise success and more enterprises in one town than another reflect a higher amount of money entering and/or circulating in the first than the second town. The basic reason for the difference between the numbers of enterprises in a village compared to those of a large town is the differing amounts of money available to enterprises in them. Such differences explain the range of overlapping town sizes encountered in the river group and the Great Karoo group.

Many of the regression equations between the total number of enterprises in a group and the number of enterprises in a specific sector explain virtually all of the variances of the sector enterprises (Tables 5 and 6). The second lesson deals with the implication of this from an entrepreneurial point of view. Because towns are not all of the same age, the implication is that 'entrepreneurial space' in those sectors with regression equations of the above kind is used very effectively by what are probably 'run-of-the-mill entrepreneurs'. If entrepreneurial space becomes available new 'run-of-the-mill entrepreneurs' move in fairly rapidly. Also when too many entrepreneurs enter such a business sector in a town competition will quickly reduce the number to the 'right' level for that town. Figure 3 illustrates the above situation very clearly. A point to ponder is that the above observations have implications for black economic empowerment (BEE) programmes because new BEE entrepreneurs in certain sectors might be set up to fail or, if they do not fail, then they will drive some other entrepreneur(s) to failure.

The regression equations of the economic driver sectors (Table 5) explain much lower variances than those of the services sectors (Table 6) and this is true for both groups. The third lesson is that a different kind of entrepreneurial space probably operates in these sectors, one that requires 'special entrepreneurs' that can 'see' non-obvious business opportunities.

The fourth lesson pertains to the needs of the buyers of products and/or services. Enterprise customers have different needs (Beinhocker, 2006). Therefore towns will give rise to different types of businesses and in proportion to the needs of the customers present in the towns. Van der Merwe and Nel (1975) referred to 'threshold populations', i.e. the minimum population needed to support a single enterprise of a particular type and pointed out that this is a useful concept. The data presented in Tables 5 and 6 support this contention, albeit in a different form. The regression coefficients of equations with highly significant correlations in Tables 5 and 6 can be interpreted as 'carrying capacities' (the ratio of the number of enterprises in a specific sector per unit of the total number of enterprises), which enable a predictive capability about enterprise development in South African towns and which justifies further examination.

The fifth lesson is that the degree of utilisation of certain business sectors differs statistically significantly between clusters of towns. Toerien and Seaman (2010) reported a similar phenomenon and suggested that there are different evolutionary paths available to towns. More information is needed about the factors that drive the different evolutionary paths and how these can be used to meet the challenges of rural South Africa.
The last lesson is that approaches and tools used effectively in the study of ecology offer many potential advantages for the study of enterprise development dynamics, as illustrated in this study. This study showed that the mere presence of abundant water in a region would not automatically translate into enterprise development in towns and in this way alleviate the unemployment problem of rural areas. Entrepreneurial development should probably focus on ways and means to increase the flow of money into towns and not merely on its circulation within communities.

\section{Acknowledgements}

The financial support of the Centre for Environmental Management, University of the Free State, the advice of Steve Mitchell, the help of Marie Watson with the use of PRIMER, the support of Frank Sokolic with the preparation of maps, the library support of Annamarie du Preez and Estie Pretorius, and the analytical support of Marie Toerien are gratefully acknowledged.

\section{References}

ASHTON PJ and TURTON AR (2008). Water and security in SubSaharan Africa: Emerging concepts and their implications for effective water resource management in the Southern African region. In: Brauch HG, Grin J, Mesjasz C, Behera NC, Chourou C, Spring UO, Liotta PH and Kameira-Mbote P (eds.) Globalisation and Environmental Challenges: Reconceptualizing Security in the $21^{\text {st }}$ Century. Springer Verlag, Berlin.

BEGON M, HARPER JL and TOWNSEND CR (1990) Ecology: Individuals, Populations and Communities. ( $2^{\text {nd }}$ edn). Blackwell Science, Cambridge, MA.

BEINHOCKER ED (2006) The Origin of Wealth: Evolution, Complexity, and the Radical Remaking of Economics. Harvard Business School Press, Boston.

CLARKE KR and GORLEY RN (2006) PRIMER v6: User manual/ tutorial. PRIMER-E Ltd, Plymouth.

CLARKE KR and WARWICK RM (2001) Change in Marine Communities: An Approach to Statistical Analysis and Interpretation ( $2^{\text {nd }}$ edn.). PRIMER-E Ltd, Plymouth.

COWLING RM (1986) A Description of the Karoo Biome Project. South African National Scientific Programmes Report No. 122, Council for Scientific and Industrial Research, Pretoria.

DYTHAM C (2003) Choosing and Using Statistics: A Biologist's Guide ( $2^{\text {nd }}$ edn,). Blackwell Science, Malden MA.

ERASMUS BPJ (2004) Op Pad in Suid-Afrika (2nd edn.). Jonathan Ball, Jeppetown.

FERREIRA SL A, VAN DER MERWE IJ and ZIETSMAN HL (2007) Natural resource base as predictor of town growth and development potential in Western Cape Province. Geogr. 92 26-41.

FRANSEN H (2006) Old Towns and Villages of the Cape. Jonathan Ball Publishers, Johannesburg.

GILIOMEE H and MBENGA B (2007) New history of South Africa. Tafelberg, Cape Town.

MYBURGH DW (1978) The origin of towns in the Eastern Cape Midlands. Contree 4 25-30.

NKWINTI G (2010) It is the time for rural people to experience the desired change that we have all talked about. Progress Report. $A N C$ Today 10 (13) 1.

TOERIEN DF (2005) Taming Janus: Technology, Business Strategy and Local Economic Development. DTK, Stilbaai.

TOERIEN DF and SEAMAN MT (2010) The enterprise ecology of towns in the Karoo, South Africa. S. Afr. J. Sci. 106 1-10.

VAN DER MERWE IJ and NEL A (1975) Die Stad en sy Omgewing: ' $n$ Studie in Nedersettingsgeografie. Universiteitsuitgewers, Stellenbosch.

WICKINS PL (1983) Agriculture. In: Coleman FL (ed.) The Economic History of South Africa. HAUM, Pretoria. 